\title{
Evaluating the Trend in Managing Human-Wildlife Conflicts in and around Akagera National Park, Rwanda
}

\author{
Celestin Banamwana ${ }^{*}$, Pierre Dukuziyaturemye ${ }^{1}$, Gaspard Rwanyiziri² \\ ${ }^{1}$ Department of Environmental Health, College of Medicine and Health Sciences, University of Rwanda, \\ P.O Box 3286, Kigali, Rwanda \\ ${ }^{2}$ Department of Geography and Urban Planning \& Centre for GIS and Remote Sensing (CGIS), College of \\ Science and Technology, University of Rwanda, P. O Box 3900, Kigali, Rwanda \\ *Corresponding Author: cbanamwana@,nursph.org \\ DOI: $10.4314 /$ rjeste.v4i1.10 \\ https://dx.doi.org/10.4314/rjeste.v4i1.10
}

\begin{abstract}
Human-Wildlife Conflict (HWC) makes wildlife conservation more difficult and threatens the endangered species and human livelihood in adjacent protected areas. While the cases of existing conflicts are often evaluated, their trend vis-à-vis the mitigation measures such as an electric fence has been frequently overlooked. This study aimed at evaluating the trend of human-wildlife conflicts in and around Akagera National Park (ANP) by comparing the situations before and after its electric fencing. This study used both secondary and primary data. Secondary data used exiting literature while primary data has been obtained by using field observation, household questionnaire survey, and Key Informant Interview with park managers and local leaders.

The findings revealed that both illegal activities from local population and damages from wild animals have significantly reduced if we compare the situations before and after the establishment of an electric fence around ANP in 2013. In fact, between 2011 and 2020, illegal activities in the park have reduced to $70 \%, 80 \%, 85 \%$, and $80 \%$ for captured cows, caught poachers, found traps, and killed animals respectively. However, this electric fence has not yet eradicated all forms of human-wildlife conflicts to the extent of zero case. In this regard, a set of sustainable communitybased conservation strategies such as revenue sharing scheme, insurance scheme, compensation measures, etc., is highly encouraged.
\end{abstract}

Keywords: Human-Wildlife Conflict, Illegal Activities, Electric Fence, Local Population, and Community-Based Conservation 


\section{Introduction}

Human-Wildlife Conflict (HWC) has been in existence as long as humans and wild animals have shared the same landscapes and resources (Bariyanga et al., 2016). The HWC evidence has recently demonstrated that the "Taung skull", the most famous hominid fossil, which was discovered in South Africa in 1924, belonged to a child who was killed by an eagle two million years ago (White and Edwards, 2000). Pre-colonial and early nineteenth-century historians describe areas in Africa and other parts of the world where elephants invaded human cultivations, causing food shortages and leading to the displacement of settlements (Hoare, 1999). Some authors in the field of conservation blame colonialism for its contribution in ruining the harmonious relationship that existed for many years between wildlife and local people. This was done by creating Protected Areas (PAs) where wild animals and local communities have been separated by different types of fences, rules and regulations (Dennis Babaasa, 2015; Rutagarama \& Martin, 2006).

In Africa, the creation of PAs in different colonies has been interpreted as a kind of domination of colonists against indigenous people when white men from Europe started to exclude local people from their ancestral lands for conservation purposes. Some known stories are the cases of Masai communities in Kenya and in Tanzania, Iks community in North-Eastern part of Uganda, or the case of Batwa groups in Rwanda and Burundi (Rwanyiziri, 2009). This exclusion of local people during the establishment of PAs was considered as a kind of marginalization because local people were denied some traditional and legitimate rights that they used to have before the creation of those spaces (Shemwetta and Kideghesho, 2000). Rwanda has also encountered such type of colonial governance in its protected areas. This began when Belgian colonizers removed Batwa groups and some agro-pastoralists from their ancestral lands in order to create Volcanoes National Park (VNP) and Akagera National Park (ANP) in 1925 and 1934 respectively (Apio, Plath, and Wronski, 2015). This was implemented by putting in place a set of laws and severe punishments against local people who tried to enter those protected spaces illegally. On the side of local people, this coercive approach of conservation has created in their mindsets a kind of negative attitudes towards the management of PAs. In practice, this frustration was transformed by illegal activities such as poaching, encroachment, etc. (Rwanyiziri, 2009). 
These illegal activities have been frequent in and around all Rwandan PAs and have had negative impacts on their natural resources as well as on local community livelihoods. This happened since their establishment in 1930s until 2004 when there was a shift from this fortress conservation approach to the one of community-based conservation. In addition, PAs and wildlife populations were significantly impacted by the war of 1990-1994. After the 1994 Genocide against Tutsi, the new government, led by Rwanda Patriotic Front (RPF), decided to settle old refugees and their cattle by reducing 2/3 of ANP surface (Hill, 2002). Consequently, the number of conflicts between wild animals and farmers in and around ANP has increased due to the competition for available resources. Crop raiding has been one of the main damages caused by wild animals where elephants and other animals used to destroy many crops of farmers adjacent to ANP. At the same time, some predators such as lions were poisoned by cattle keepers to near extinction while other mammals were shot and trapped for bush meat (Bariyanga et al., 2016).

Beside many initiatives in terms of law enforcement and community-based conservation, this situation of WHC has continued until 2013 when the Government of Rwanda, in partnership with African Parks Network, through Akagera Management Company (AMC), has established an electric fence around ANP. Yet, some incidences such as crop-raiding and illegal poaching are still happening, but their number has significantly reduced between 2013 and 2020. The purpose of this study was to evaluate and demonstrate the trend of HWC vis-à-vis the measures put in place to manage ANP resources. In addition, the study wanted to establish the appropriate options to minimize the existing HWC towards a sustainable wildlife management as well as an improved community livelihood around the park.

\section{Materials and Methods}

\subsection{Study Area Description}

This study has been conducted in and around ANP in two districts bordering ANP namely Kayonza and Gatsibo districts of the Eastern Province. Within those districts three cells that are adjacent to the park and where WHC are frequent were selected for household field survey. Those cells are Kiyovu (Ndego sector) and Kageyo (Mwiri sector) in Kayonza District, and Munini (Rwimbogo sector) in Gatsibo District. In terms of socio-economy activities, famers who practice both 
agriculture and cattle keeping occupy all these cells. However, in many places that are very adjacent to the park, cattle keeping are the most practiced.

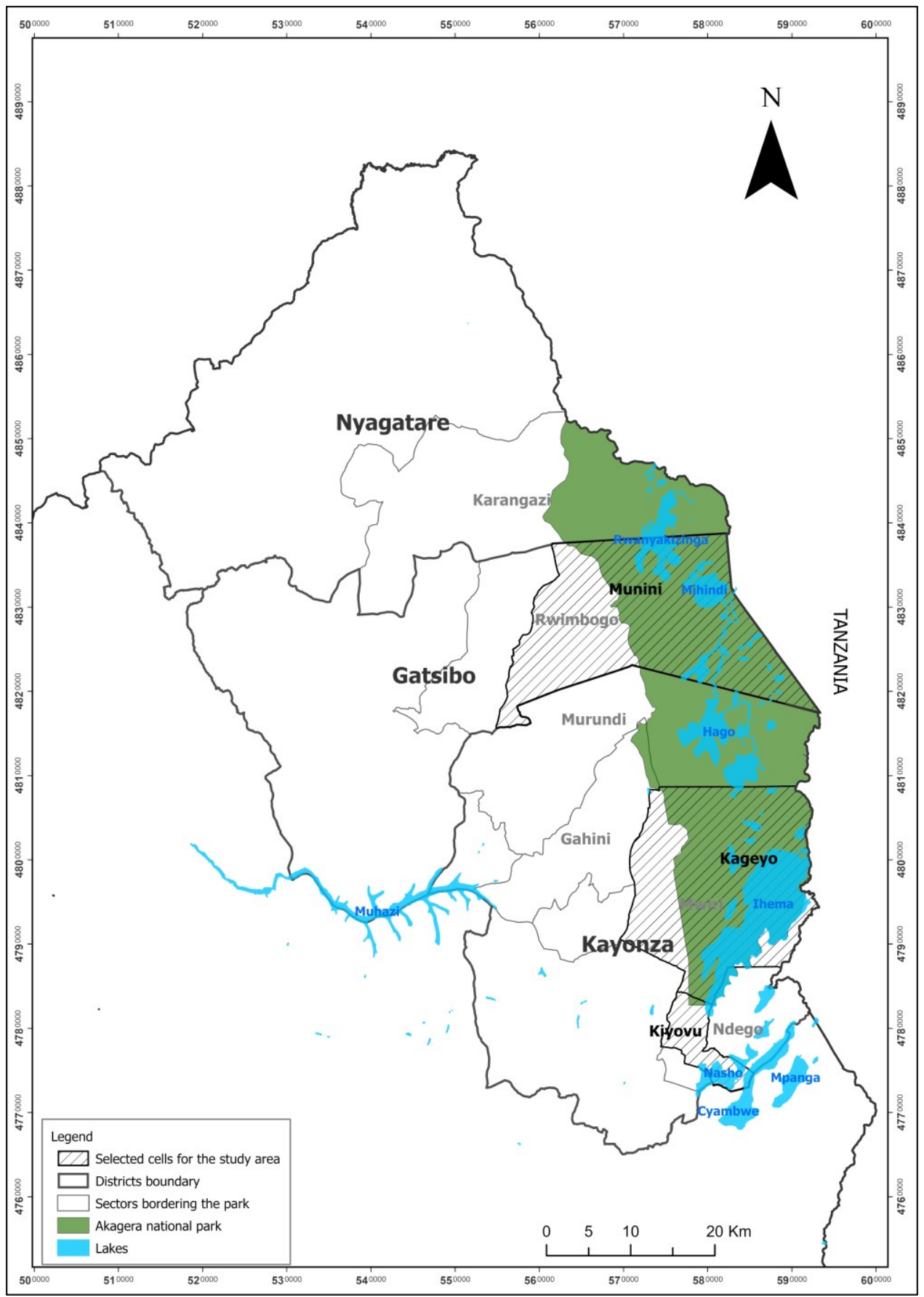

Figure 1: Location of the Study Area (CGIS, 2021) 


\subsection{Data Collection Techniques}

\subsubsection{Secondary Data}

A consolidated literature from different sources of data has been used in this study. Firstly, we consulted available data (both quantitative and qualitative) in two important institutions in charge of ANP that are the Department of Tourism and Conservation of Rwanda Development Board (RDB) and Akagera Management Company (AMC). Secondary, we consulted different technical reports, academic publications (theses, scientific papers and books) on different aspects of conservation here in Rwanda and elsewhere. Finally, we contacted specific researchers or experts who have been working on protected areas in Rwanda in order some useful data that helped in analyzing different aspects related to our study. At the end, it was a combination of different sources of data that helped to obtain a useful and reliable bank of secondary data.

\subsubsection{Primary Data}

In order to generate quantitative data, a structured household questionnaire survey was given to each head of household among local people who are leaving near ANP. This was done after an agreement of participation. The questionnaire survey was translated into Kinyarwanda and the questions were related to the type of illegal activities from local population as well as the damages caused by wild animals to the local community. The simple size was obtained by using stratified random sampling where three sectors adjacent to the park were selected. These sectors are Ndengo and Mwili in Kayonza district, and Rwimbogo in Gatsibo district.

The sample size was calculated in each stratum according to the total population of each sector following the Yemen formula as described by Asselin (1978). The strata were the cells that are closer to the park. In this regard, three cells namely Kiyovu (Ndengo sector), Kageyo (Mwiri Sector), and Munini (Rwimbogo sector) were selected. At the end, a total of 119 households have

been calculated based on selected three cells. According to the formula, 31 people from Kageyo Cell, 51 from Munini Cell, and 37 Kiyovu Cell participated to the household survey. Apart from the use of household questionnaire survey, this study collected qualitative data by using structured interviews with local authorities and park managers from Akagera Management Company (AMC) and the Department of Tourism and Conservation within RDB. 


\subsection{Data Analysis}

Quantitative data were analyzed in Excel sheet with a descriptive statistics model, which generated frequency distributions on different aspects of $\mathrm{HWC}$, the inter-annual variation of threats caused by human activities to the park as well as damages caused by wild animals to local population living around ANP. Qualitative data were analyzed according to the current situation of HWC, and proposed options of conflict management in and around the park. At the end, both quantitative and qualitative data have been triangulated to make the meaning of the trend of HWC management before and after electric fencing of ANP. Quantitative data was completed by qualitative data that resulted from interviews and personal observation from the field.

\section{Results}

\subsection{Threats from Wild Animals}

Between 2006 and 2011, crop raiding, injuries, and human deaths have been reported as serious cases around ANP. However, the trend has turned down after electric fencing and the data of 2020 showed a reduction of almost $75 \%$ of crop raiding and $50 \%$ of injuries and Deaths.

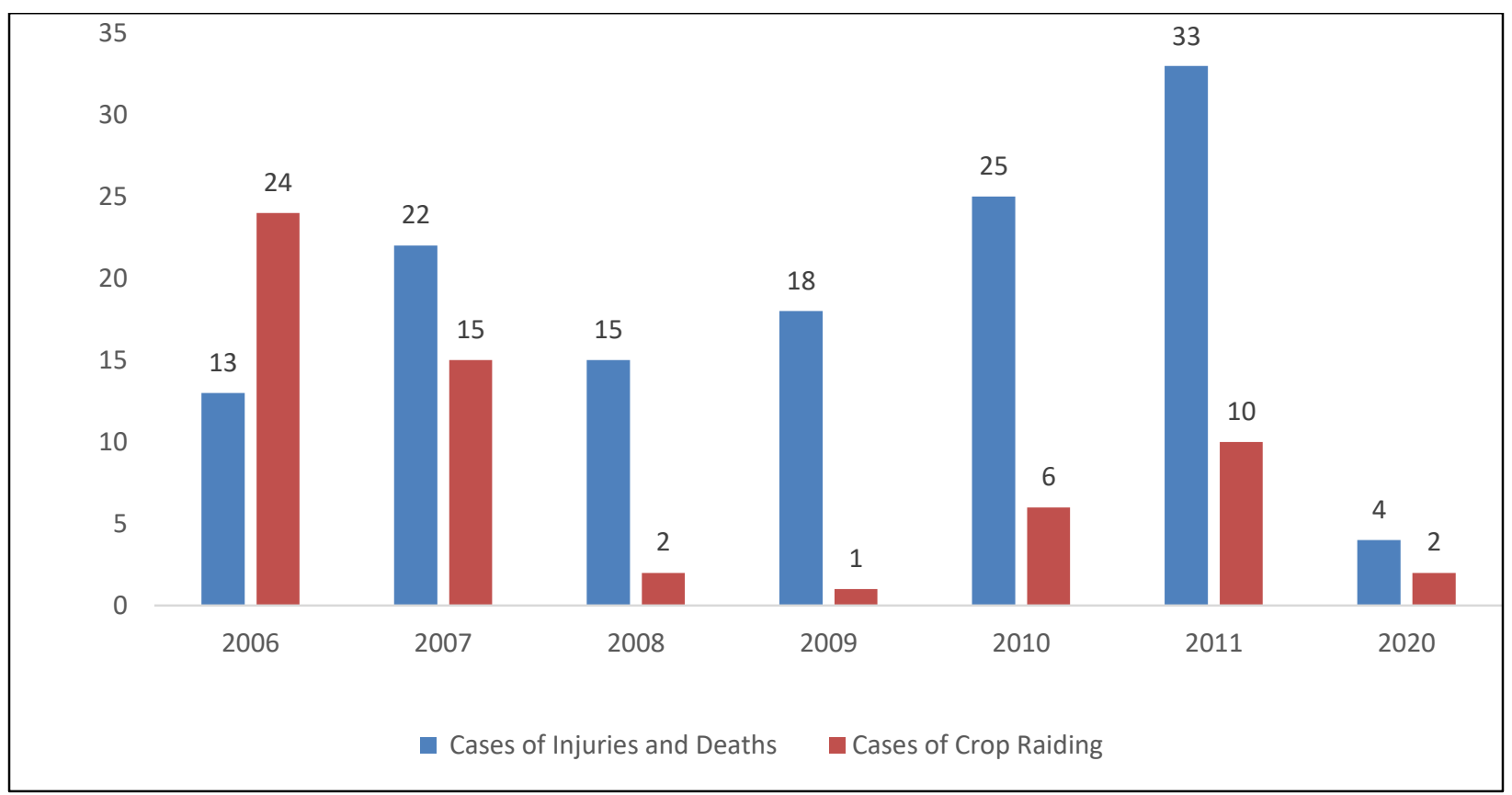

Figure 2: Wild Animals' Threats to Local Community (RDB, 2012; AMC, 2021) 


\subsection{Threats from Human Activities}

According to the statistics on illegal activities from ORTPN (2006 - 2010) and RDB (2011), pastoralists living near the park, Rwandan and Banyambo poachers (from Tanzania), are the main categories of local population who threaten biological resources of ANP. However, recent statistics from AMC has shown a significant decrease of those activities after the electric fencing of the park in 2013. The following figure is showing the frequency of these illegal activities according to their nature.

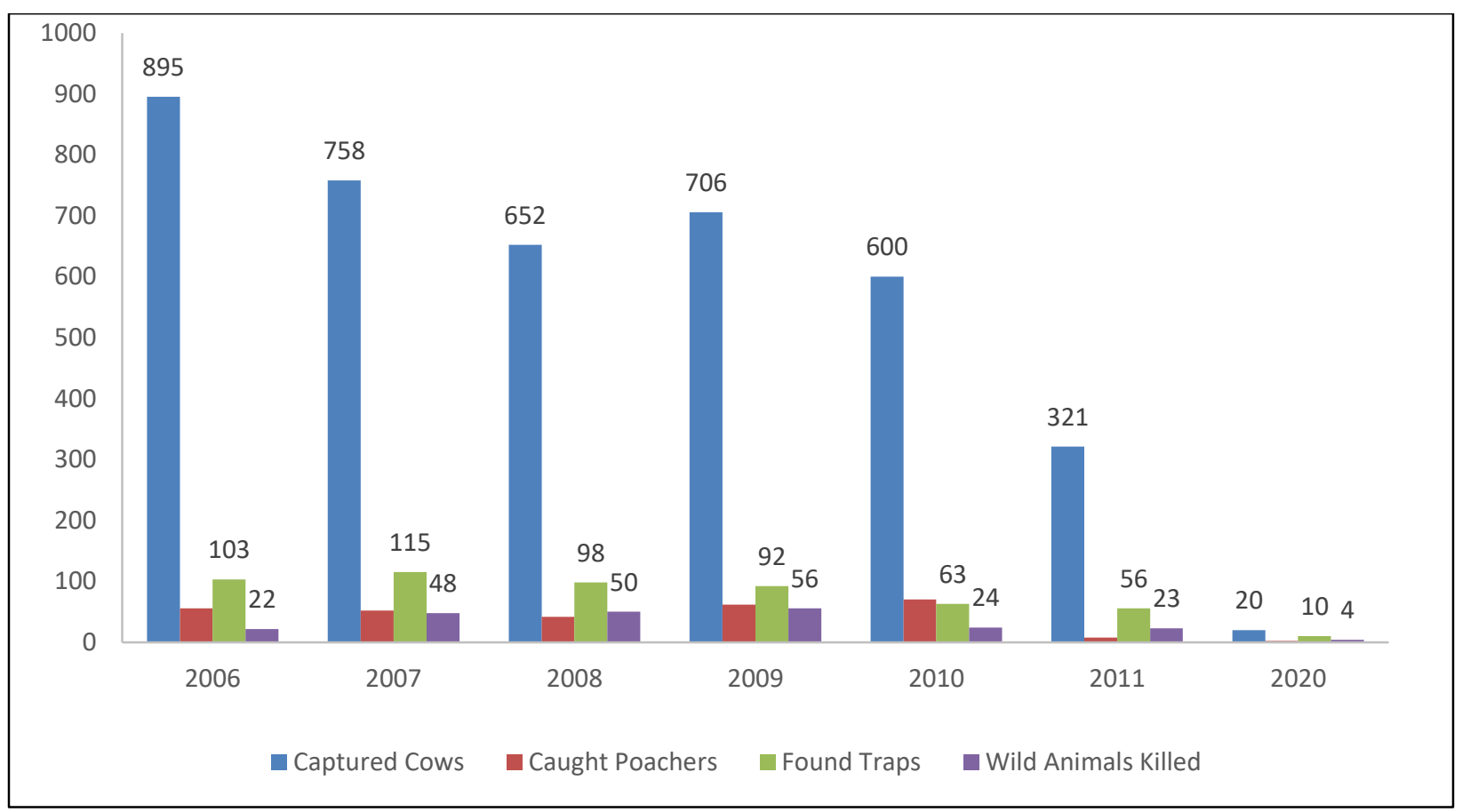

Figure 3: Illegal Activities in ANP before and after Its Electric Fencing of 2013 (RDB, 2012 \& AMC, 2021)

According to the Figure 3, illegal activities from local population within the park have systematically reduced between 2005 and 2011. In fact, in 2006, 919 cows were captured, 193 traps were found, 10 wild animals were killed and 32 poachers were caught in the park. Five (5) years later in 2011, these statistics have decreased of $66 \%, 71 \%, 20 \%$ and $29 \%$ for captured cows, found traps, killed wild animals and caught poachers respectively. This reduction is linked to the mass sensitization of the local community around the park, through environmental education related activities, and the benefits form tourism revenue sharing scheme where some development 
projects have been initiated and basic infrastructure (schools, health centres, etc.) developed. After the fencing of the park, all these illegal activities have decreased significantly.

\subsection{Alternative Solutions towards the Sustainable Management of ANP}

Management strategies such as the establishment of electric fence, different community-based conservation approaches such as revenue sharing scheme, compensation and development projects, are discussed in this study as it indicated in the figure below.

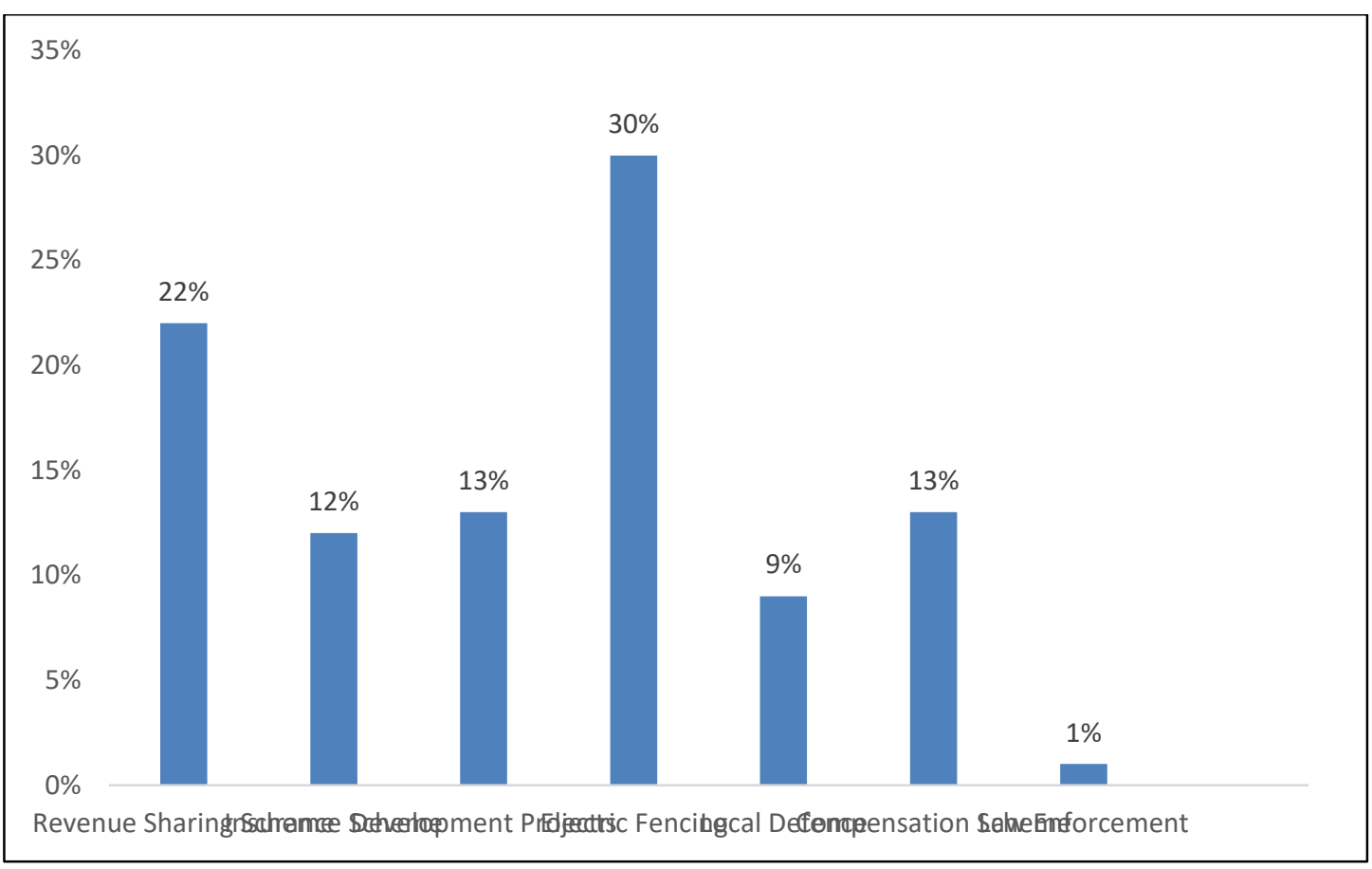

Figure 4: Possible Strategies for Reducing HWC in and around ANP (Field Work, 2020).

According to our field survey, the majority of respondents (30\%) mentioned the construction of the electric fence as the most sustainable solution to the problem of HWC around ANP. Benefits from tourism revenue sharing scheme (22\%) came as the second effective measure with $22 \%$ of respondents. Other effective measures include development projects (13\%), compensation scheme $(13 \%)$, insurance scheme $(12 \%)$, local defense $(9 \%)$, and law enforcement $(1 \%)$. 


\section{Discussion}

\subsection{Effectiveness of Electric Fence towards Crop raiding, Injuries, and Deaths}

This is a strategic method used to keep off wild animals in PA due to its physical barrier to migratory species (Kioko et al., 2008). When it is well designed, constructed, and maintained, it could be effective for the prevention of some conflicts between people and wild animals. In case of cast away the permanent problems caused by the wild animals to the community around the ANP, the Government of Rwanda through RDB in partnership with the African Parks Network Project decided to erect the electric fence around ANP. On the one hand, the majority of respondents were agreeing that this technique could be an effective protection for some problems caused by wild animals. This was also emphasized by the local authorities and park managers where one local authority highlighted that "a such preventive method will reduce the burden of compensation of the Government through RDB but will not eradicate the existing conflicts as long as the farmers are suffering overgrazing". On the other hand, some authorities and park managers criticized the application of an electric fence to a small park such as ANP as a disturbance of wildlife. The same finding is coherent with the ones in the study done on the effectiveness of electric fence around ANP (Bariyanga et al., 2016)

Fencing reserves are disturbing the animal's home range by affecting the wildlife population's dynamics and interrupt their natural migratory and dispersal behavior. Especially for the animals which use a wide range area like big mammals by Lamarque et al. (2009). From 2006 to 2011, the Wild animals raided the crops and finally, the farmers bear the costs of losing their livelihood food resources. Some people preferred to give up cultivating some crops simply because they know that wild animals like to raid them. Thus, it doesn't matter to the west their time and energy (Mc Guinness \& Taylor, 2014). However, the situation has turned up by implementing the fencing policy. As result, the cases of crop-raiding, injuries, and death have reduced dramatically which is in the same context of the study done in Kenya (Kioko et al., 2008). Even though, such a reduction of wild animal incidences adjacent to the parks, yet some incidences are still presented as presented in Fig. 2. In general, electric fencing for ANP is not a panacea for a guaranty of managing HWC; it has a few ecological and economic disadvantages and it cannot be ranked 100\% efficient. 


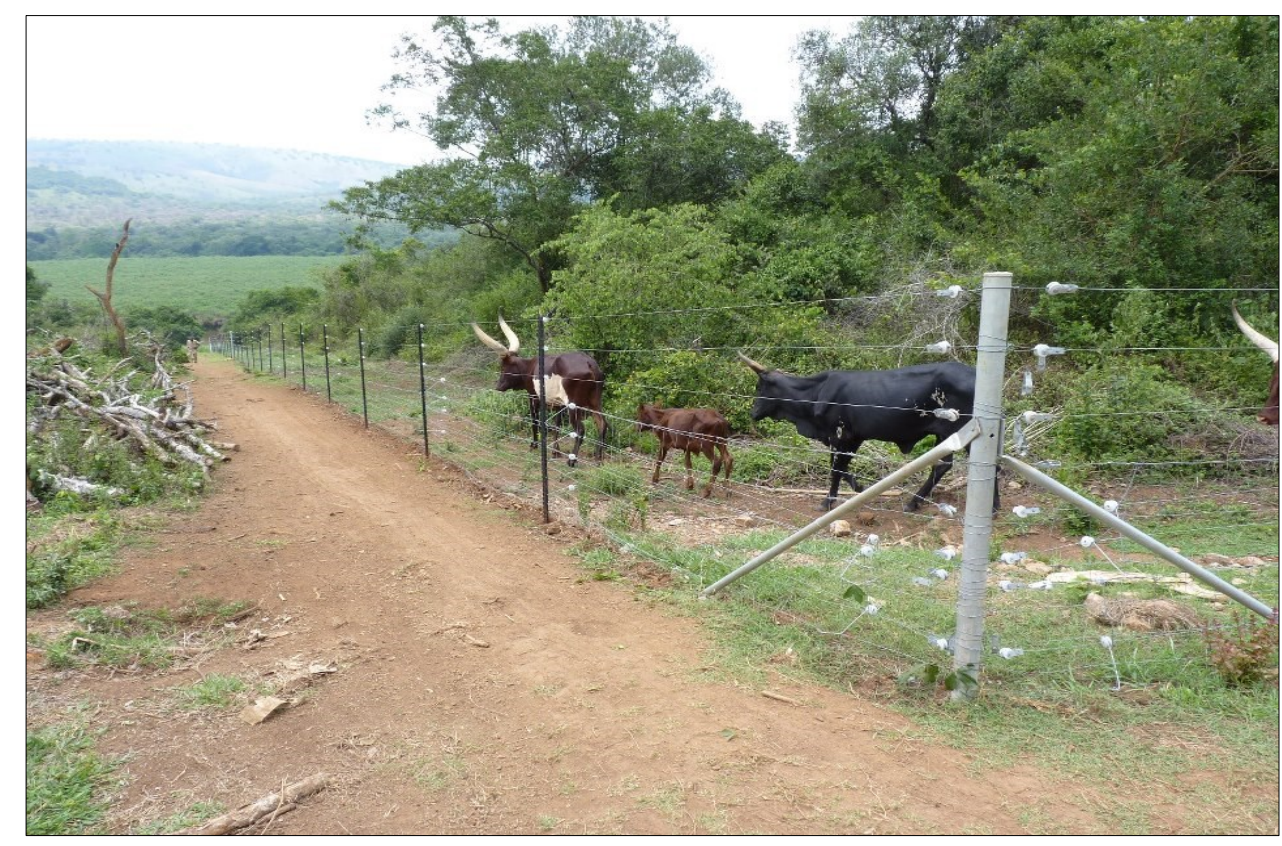

Figure 5: Electric Fencing around ANP (Credit: RDB, 2013).

\subsection{Community-Based Conservation (CBC)}

This new conservation paradigm, so-called 'Community Conservation' (CC), was considered as a means of reconciling wildlife and human is by ensuring that the interests and knowledge of local communities were taken into account (Adams \& Hulme, 2001). This new approach restricted by ORTPN in 2002 aimed to integrate the local people in the management of PAs. The style of hierarchical system management is based on the colonial system of governance of PAs and the current structure of RDB ( $\mathrm{T} \alpha \mathrm{C}$ ) which is restricted in such a way the community is not involved in the power decentralization. Both factors don't allow the active participation of the community in conservation as stakeholders. Although this integration is still in an immature stage, from its establishment in law 2002 until today, it is theoretical participation and excludes local communities in different practices of conservation.

Even though this approach is still criticized on which level and how the community could participate, it is the best strategy on which all techniques could take the basis for eradicating the HWC around ANP as indicated by the majority of respondents in Munini, Kiyovu, and Kageyo cells (see the Figure 4). 
The community-based conservation could be seen in the angle of "participation" which can be envisaged at different levels. Certain types of participation have a significant meaning and a chance of success in the management of PAs. Such types of passive, consultative, and bought participation cannot be successful in wildlife conservation. However, functional, interactive, and self mobilization participation shows the best guarantee of sustainability in wildlife and human management as shown in Marykey (2011, cited in Pretty, 1995). In general, these levels of participation of communities are not yet achieved in PAs of Rwanda and ANP could serve as a good example.

The level of participation will depend on the effort made in different policies used by the conservation actors so that the community around the park could forward and be motivated in the program. Some facts such as revenue sharing scheme, the culture of loving wildlife, and environmental education could be tools to improve community implication more in management in HWC whenever it occurs.

\subsubsection{Revenue Sharing Scheme}

The Program started in 2005 aimed to develop the community around the park. It has contributed to the improvements of community-park relations around the park where the program occurs. The program is under RDB (Tourism and Conservation Department), and it is nicknamed 'Milk of the Gorillas (Dennis Babaasa, 2015).

The initial scheme provided 5\% of the revenues of the country's three national parks, particularly Volcanoes National Park with its gorilla-based tourism. In the period (2006-2009), 40\% of this amount, some 650,000 USD, was spent in education, water, and agricultural projects, in 9 out of the 12 sectors bordering Volcanoes National Park as cited in Scholte (2011).

The program can help the community around the ANP to overcome poverty as the main cause of HWC. There is a tendency of District and Sectors authorities to select social infrastructure such as schools and health centers to meet their performance contracts. However, the communities are not aware of such projects with conservation logic and they do not understand the link between these projects and the park. Also, they don't see the link of those projects to their crops raided they 
always suffer. Therefore, it is doubtful if the poor people practiced the choice of this infrastructure and it is assumed that poor people don't have a voice.

\subsubsection{Development Projets}

The short-term and long-term projects have been initiated around ANP for local people interests and for community conservation. In the framework of community integration in the conservation activities of the ANP. Since, 2006, there was an implementation of diverse foreign projects aimed to support community to cohabite in friendly manner with the park either through behavior change or change of household income. It is known that many foreign projects have failed to achieve the goal of reconcile the human and conservation interests in limited income countries (Sun, Bariyanga, \& Wronski, 2018). This is supported by one of interviewee who said that: "many projects operated around ANP have been destroyed instead of being developed at immature stage and the community was unable to maintain the progress achieved with others projects".

The ANP is currently managed by African Parks Network projects (APN). Apart from the above projects, the communities around the park have created cooperatives of agriculture and /or pastorates to enhance their powerful development. However, such organized practice alone, could not be an effective option for sustainable management of ANP which comply with the findings in the review on the factors affecting the success of conservation in Africa (Muhumuza \& Balkwill, 2013). The same review point out the socio-cultural context linked to the creation of the park and its management as the core aspects of the community based-conservation. It is clear that the development projects are one of the tools to reduce the conflicts, when are mainly based on extreme poverty near the park. However, the main problem that occurs with different projects on the site is lack of clear understanding of the source of conflicts, coordination and joining for the same orientation which challenges the sustainability of projects. One respondent highlighted that "African Park Networks project is constructing the electric fence by employing the local people for money provision without consideration the boundaries of our pastoral land". 


\subsubsection{Compensation Scheme}

Prime Minister's order $n^{\circ} 26 / 03$ of 23/05/2012 determining the rates, calculating method and criteria for determining compensation to the victim of damage caused by an animal. This prime minister's order has been established after accumulated claims of crops raided, injuries, died cases of people, and also property destruction around the ANP. Besides the all claims were addressed to the Government through RDB which is in charge of PAs.

The Prime minister's order covers the claims of local people and clarifies the whole process of compensation and requirements. However, a recent study on compensation scheme (Watve, Patel, Bayani, \& Patil, 2016) criticize the existing visual model of estimate of loss as fact of subjectivity, which leads to enhance the conflicts among victims. Although, the assessment of damage is left in the hands of personal under judgment or negotiate with victim and compensating part, it is difficult to correlate the visible damage with the actual grain productivity. According to the respondents of Kageyo, Munini, and Kiyovu cells highlighted that the method and process of calculating the damage values are unfair. Some claims are rejected and others are not accounted for because of late reporting when the evidence and some signs are not viable or long distance from the park manager's office.

One of the local leader said, "Sectors' agronomists and park officers have confirmed the damages and their values and reporting to RDB without an overview of the victims. Consequently, the people around the park are not satisfied with little value attributed to their properties".

A major benefit that compensation programs can increase tolerance of wildlife and promote more positive attitudes and support for conservation (Hill, 2002). Rwanda has also established through RDB a Special Guarantee Found (SGR) in line with the Government's wildlife damage refund scheme. The 18 million francs of compensation has been provided from SGR to the people of Rwimbogo Gatsibo District due to their crops raided by wild animals and the other parts bordering ANP will follow the same process of compensation.

The SGR is critically sustainable due to the high amount of money paid for loss and as Rwanda developing country (Ngabonziza, 2010). It cannot promote compensation as the factor of HWC reconciliation because the poor people can get this opportunity as a source of overcoming poverty 
and starting to expose their properties at wild animals' risk. One of the local leaders spoke that "people can destroy the electric fence for the facility of wild animals that exit from the park".

In fact, in the United States, courts have long time viewed wildlife as res nullius (having no owner) in the sense that limiting the liability of the states (Nyhus, 2016). The farmers closer to the park become more responsible for the moral hazard problem as the ones who may know better than outsiders how best to reduce wildlife damage. Therefore, the moral hazards are resolved by forcing the farmers to act in such a way they reduce the risk of losses or by risk sharing where States pay a part of loss and others paid by the farmers themselves. Then, deductibles encourage farmers or ranchers to protect their crops and livestock (Knox, 2014). However, this conservation view was considered as a fact of exacerbating the conflicts especially in the parts of the world with limited resources where parks are source of income from tourism.

\section{Conclusion and Recommendations}

A panel of measures that can prevent or mitigate HWC is cited and discussed in this study but most of them are presenting some shortfalls. Even though there is no panacea for the management of HWC, well-designed human-wildlife conflict management plans which integrate different techniques of an electric fence, revenue sharing and compensation scheme when these are adjusted to the nature of the problem can be successful. Therefore, the potential solutions can be selected based on their effectiveness, cost, human and social acceptability.

Finally, the long-term success of wildlife conservation in ANP will dependent on local support. In this regard, the wildlife managers in ANP and residents have to acknowledge the problem and join together and agree on the best strategy for reconciling human beings and wildlife for long-term conservation and human well-being.

\section{Acknowledgment}

We acknowledge the University of Rwanda and Rwanda Development Board (RDB) in partnership with the African Parks Network to provide permission to conduct data on Akagera National Park. 


\section{Ethical Consideration}

We got permission from Rwanda Development Board (RDB) to work on the secondary data and to conduct data from the ANP under the support of the African Parks Network (APN), which currently manages the ANP.

\section{References}

Adams, W. M., \& Hulme, D. (2001). If community conservation is the answer in Africa, what is the question? Oryx, 35(3), 193-200. doi:10.1046/j.1365-3008.2001.00183.

Apio, A., Plath, M., \& Wronski, T. (2015). Recovery of Ungulate Populations in Post-Civil War Akagera National Park, Rwanda. Journal of East African Natural History, 104(1-2), 127-141. doi:10.2982/028.104.0110

Ayivor, J. S., Gordon, C., and Ntiamoa-Baidu, Y. (2013). Protected area management and livelihood conflicts in Ghana: A case study of Digya National Park. Parks, 19(1), 37-50. doi:10.2305/IUCN.CH.2013.PARKS-19-1.JSA.en

Bariyanga, J. D., Wronski, T., Plath, M., \& Apio, A. (2016). Effectiveness of Electro-Fencing for Restricting the Ranging Behaviour of Wildlife: A Case Study in the Degazetted Parts of Akagera National Park. African Zoology, 51(4), 183-191.

doi:10.1080/15627020.2016.1249954

Dennis Babaasa, E. A. and R. B. (2015). Human-wildlife conflict management: Experiences and lessons human-wildlife conflict management: Experiences and lessons learned from the prepared for the secretariat with funding from the Norwegian, (November). doi:10.13140/RG.2.1.1889.4809

Distefano, E. (2005). Human-Wildlife Conflict worldwide: collection of case studies, analysis of management strategies and good practices, 29. Retrieved from http://www.fao.org/3/aau241e.pdf

Hill, C. M. (2002). Human-wildlife conflict: identifying the problem and possible solutions, (January 2002).

Hoare, R. E. (1999). Determinants of human \pm elephant con ${ }^{-}$ict in a land-use mosaic, 689-700. Kioko, J., Muruthi, P., Omondi, P., \& Chiyo, P. I. (2008). The performance of electric fences as elephant barriers in Amboseli, Kenya. African Journal of Wildlife Research, 38(1), 5258. doi:10.3957/0379-4369-38.1.52 
Knox, A. (2014). Contested Claims Over Protected Area Resources in Policy Research Brief No 1 Over Protected Area, (1).

Mc Guinness, S., \& Taylor, D. (2014). Farmers' Perceptions and Actions to Decrease Crop Raiding by Forest-Dwelling Primates Around a Rwandan Forest Fragment. Human Dimensions of Wildlife, 19(2), 179-190. doi:10.1080/10871209.2014.853330

Muhumuza, M., \& Balkwill, K. (2013). Factors Affecting the Success of Conserving Biodiversity in National Parks: A Review of Case Studies from Africa. International Journal of Biodiversity, 2013, 1-20. doi:10.1155/2013/798101

Ngabonziza, G. (2010). A Critical Investigation Of Conservation Attitudes Of The Local Community Living Adjacent To Akagera National Park, Rwanda, (September), 35-56. Retrieved from https://core.ac.uk/download/pdf/148365463.pdf

Nyhus, P. J. (2016). Human-Wildlife Conflict and Coexistence. Annual Review of Environment and Resources (Vol. 41). doi:10.1146/annurev-environ-110615-085634

Rutagarama, E., \& Martin, A. (2006). Partnerships for protected area conservation in Rwanda. Geographical Journal, 172(4), 291-305. doi:10.1111/j.1475-4959.2006.00217.x

Rwanyiziri, G. (2009). Géopolitique de 1 ' environnement au Rwanda . Pour une gouvernance participative des espaces protégés To cite this version : HAL Id : tel-00449865 Universite de Pau et des Pays de 1 'Adour (UPPA), Institut de Recherche sur les Sociétés et l'Aménagement.

Shemwetta, \& Kideghesho. (2000). Human-wildlife conflicts in tanzania: what research and extension could offer to conflict resolution, 3(April), 569-577.

Sun, P., Bariyanga, J. D., \& Wronski, T. (2018). A literature review of mammalian research respective to the Akagera ecosystem in Rwanda. Rwanda Journal, 2(1), 1-16. doi:10.4314/rj.v2i1.1d

Watve, M., Patel, K., Bayani, A., \& Patil, P. (2016). A theoretical model of community operated compensation scheme for crop damage by wild herbivores. Global Ecology and Conservation, 5, 58-70. doi:10.1016/j.gecco.2015.11.012

White, L., and Edwards, A. (2000). Conservation research in the African rain forests: a technical handbook. Wildlife Conservation Society. 